\title{
Correspondence
}

\section{Semiconductor History}

Sir,-I recently read the article, "Relationship between Science and Technology", by M. Gibbons and C. Johnson, published in the July 11 issue of Nature $(227,125 ; 1970)$ I found it very interesting. However, it contains several errors of fact.

In the section "Development of New Techniques" the statement is made that the need for radar detectors prompted much government sponsored work in the United States, principally at Purdue and Cornell Universities. In fact, the renaissance of the crystal detector was due to work on silicon carried out in Bell Telephone Laboratories prior to the war by R. S. Ohl, G. T. Southworth, A. P. King and others under the leadership of H. T. Friis. This work preceded the government programme by several years. The government programme in this country was centred at the Radiation Laboratory at the Massachusetts Institute of Technology as described by Torrey and Whitmer. Supporting programmes on germanium were carried out later at Purdue University under the leadership of the late Dr Karl Lark-Horovitz and on silicon at the University of Pennsylvania under Dr Frederick Seitz. I am not aware of a similar programme carried out at Cornell University. Finally, R. S. Ohl, H. C. Theuerer and myself were never employed at Purdue University. Our work in this field was all done at Bell Telephone Laboratories ${ }^{2,3}$.

\section{Yours faithfully,}

Bell Telephone Laboratories Inc,

\section{J. H. SCAFF}

Murray Hill,

New Jersey 07974 ,

\section{USA.}

${ }^{2}$ Crystal Rectifiers (Radiation Laboratory Series, McGraw Hill Book Co., New York, 1948).

${ }^{2}$ Oh, R. S., and Scaff, J. H., Bell System Tech. J, 26, 1 (1947).

${ }^{3}$ Seaff, J. H., Metallurgical Trans., 1, 561 (1970).

\section{Pop Charts for Science}

Sir,--Mr E. Garfield's paper (Nature, 227, 669; 1970), though rational, is disturbing. While the quotationcoefficient of a paper, if one may call it that, is to some extent a measure of the use made of its content, it would be unfortunate if the support a scientific author receives were to be made conditional on his current position in the charts. One can imagine reasons why papers in industrial chemistry might rate higher than those in, say, topology or palaeontology. In fact, were we to confine our analysis to papers published in China, the chart leader would no doubt be Chairman Mao.

In fact, the analogy from pop music raises the covers from some of the abuses we might expect (and even, while waiting for our Nobel Golden Disk, indulge in): commercial concerns dedicated to lobbying, so that our rating might be raised? Promotional quotation-data on the relative one-upmanship of particular journals? In California nothing is impossible.

We must all accord respect to $\mathrm{Mr}$ Garfield's ingenuity in devising a means whereby an unskilled staff can score publications for reference: that our capacity for publicity should become a measure of our worthiness of support is, however, a trifle simpliste. I am reminded that, according to anecdote, one of the centurions supervising the Crucifixion remarked to his comrade, "I hear he was a great teacher". "Yeah", replied the other, "but he never published anything." The fact that his graduate students did would elude Mr Garfield's net.

Yours faithfully,

Alex Comfort

University College London,

Gower Street,

London WC1E 6BT.

\section{Disputed Pronoun}

SIR,- - Hammerton ${ }^{1}$ has attempted to refute Chomsky's ${ }^{2}$ assertion that, in the sentence "Learning that John had won the race surprised him", the pronoun him cannot refer to John. The refutation, claimed to be significant at the level of one part per million, was based on the responses of twenty people who read an ad hoc paragraph containing the sentence in question. The respondents all felt sure that, in the given context, him referred to John. It is my contention that it was an agreement of despera. tion. If him did not refer to John the paragraph would be meaningless. Hammerton's subjects had the choice of ignoring Chornsky's rule or admitting that they did not understand what was otherwise a trivial paragraph.

I also have done a poll. Hammerton's paragraph was typed and offered to twelve subjects to read. They were then asked what they thought of the penultimate sentence (the one in question). A typical reply was, "I thought I was understanding the passage till I got to that sentence. Then I had to start the paragraph again to verify who John and Bill were". All twelve readers agreed that substitution of he for John would improve the sentence and make the paragraph clear on first reading.

However, when a name denotes both a person and his public image Chomsky's rule may be relaxed. For example, in the sentence, "Learning that Heath had won the election surprised him", him can refer to Mr Heath, but not Heath. English permits Mr Heath to say "Heath won" but it does not permit John to say "John won" unless John is a king or a second person with that name.

After we understand the linguistics of well constructed sentences will be early enough to tackle sentences like this one or Hammerton's paragraph.

\section{Yours faithfully,}

\section{Edward Argyle}

Dominion Radio Astrophysical Observatory,

Box 248,

Penticton, BC, Canada.

1 Hammerton, M., Nature, 227, 202 (1970).

Chomsky, N., Language and Mind (Harcourt, Brace and World, New York, 1968). 